УДК 658.012.3

\title{
ПІДВИЩЕННЯ КОНКУРЕНТОСПРОМОЖНОСТІ МАЛОГО ПІДПРИСМСТВА ЗА РАХУНОК ВИКОРИСТАННЯ БЮДЖЕТУВАННЯ РЕКЛАМИ
}

\author{
Бутенко О. П., к.е.н., доцент, \\ Головченко К. В., магістр (ХНУБА)
}

\begin{abstract}
У статті обтрунтовано необхідність використання елементів бюджетування на малих підприємствах для підвищення їх конкурентоспроможності. Для иього складені характеристики використання бюджетного рекламування підприємств великого та малого бізнесу, встановлені причини небажання керівників використовувати цей метод на підприємстві, запропоновані напрями їх мінімізації. Наведено алгоритм послідовності виконання бюджетування реклами за методом «Виходячи з цілей $i$ завдань», а також запропонована методика економічного обтрунтування прийнятого рішення з бюджетування реклами малого підприємства. Економічні розрахунки виконані на прикладі діяльності торгівельного підприємства .

Ключові слова: бюджетування, управління малим бізнесом, бюджетування реклами на малому підприсмстві за методом "Виходячи $з$ цілей $і$ завдань", конкурентоспроможність малого бізнесу.
\end{abstract}

\section{ПОВЫШЕНИЕ КОНКУРЕНТОСПОСОБНОСТИ МАЛОГО ПРЕДПРИЯТИЯ ЗА СЧЕТ ИСПОЛЬЗОВАНИЯ МЕТОДА БЮДЖЕТИРОВАНИЯ РЕКЛАМЫ}

\author{
Бутенко Е. П., к.э.н., доцент, \\ Головченко К. В., магистр (ХНУСА)
}

B cтатье обоснована необходимость использования элементов бюджетирования на малых предприятиях для повышения их конкурентоспособности. Для этого составлен характеристики использования бюджетного рекламь предприятий крупного и малого бизнеса, установлены причины нежелания руководителей использовать этот метод на предприятии, предложеннье направления их минимизации. Приведен алгоритм последовательности выполнения бюджетирования рекламы по методу «Исходя из целей и задач», а проведен анализ результатов использования бюджетирования рекламы на малом предприятия. Экономические расчеты выполнены на примере торгового предприятия.

Ключевые слова: бюджетирование, управление малым бизнесом, бюджетирование рекламы на малом предприятии по методу «Исходя из целей и задач», конкурентоспособность малого бизнеса.

(C) Бутенко О.П.,

Головченко К.В.

Вісник економіки транспорту і промисловості № 60, 2017 


\title{
INCREASING THE COMPETITIVENESS OF THE SMALL ENTERPRISE, ACCORDING TO THE USE OF ADVERTISING BUDGETARY METHOD
}

\author{
Butenko O. P., Candidate of Economic Sciences, Associate Professor, \\ Golovchenko K. V., Master \\ (Kharkiv National University of Construction and Architecture)
}

The article substantiates the need to use elements of budgeting at small enterprises to increase their competitiveness. For this purpose, the characteristics of the use of budget advertising of large and small business enterprises, the reasons for the managers' reluctance to use this method at the enterprise, the directions of their minimization are proposed. The algorithm of budget execution of advertising by the method "Based on goals and objectives" is presented, as well as the proposed method of economic substantiation of the decision made on advertising budgeting of a small enterprise. Economic calculations are made on the example of a trading company.

Key words: budgeting, small business management, budgeting of advertising on a small enterprise by the method "Based on the goals and objectives", the competitiveness of small business.

Постановка проблеми та її зв'язки
3 науковими чи практичними завданнями. Згідно зі світовими даними тенденцій малого бізнесу, тільки 40\% малих підприємств $є$ прибутковими, $30 \% \epsilon$ беззбитковими і $30 \%$ втрачають кошти [1]. Стан розвитку малого бізнесу в Україні заслуговує окремої уваги через економічну нестабільність та політичну ситуацію, яка виникла в країні у даний час. Малі підприємства сьогодні займають велику частку серед вітчизняних підприємств. I хоча, за даними аналітичного звіту Державної служби України $з$ питань регуляторної політики, ïх частка зменшилась на 5,4\%, суб'єкти малого підприємництва становлять 94,28\%-94,45\% від загальної кількості [2]. За даними Державної служби статистики України показники структурної динаміки по суб'єктам господарювання мають негативну тенденцію. Так за період 3 2015-2016 рр. кількість малих підприємств зменшилась на $11,1 \%$, мікропідприємств $12,8 \%$. Зменшення показників кількості фізичних осіб-підприємців суб'єктів малого підприємництва становить 4,3\%, а мікро підприємництва зменшилась на
73 548, що становить 4,5\% у порівнянні 3 попереднім роком [2]. Статистичні дані нашої країни підтверджують світову тенденцію стану малого бізнесу, та не розкривають причин та проблем, що постають у процесі ведення бізнесу. Перед підприємцями завжди стоїть завдання пошуку шляхів забезпечення виживання, але для керівників малого бізнесу ці завдання $\epsilon$ специфічними через брак фінансових та інших ресурсів, низьку інвестиційну активність, недоступність кредитних ресурсів тощо [3].

Виділення невирішених частин загальної проблеми. Прагнення нівелювати негативний вплив 3 боку конкурентів спонукає підприємців малого бізнесу шукати нові ринки, інноваційну продукцію, активно використовувати маркетингові комунікації. Тому обов'язковим для керівників великого i середнього бізнесу $\epsilon$ використання методів планування та контролю, поєднання яких $є$ бюджетуванням діяльності. Бюджетування на таких підприємствах відбувається на підставі зведення бюджетів усіх підрозділів діяльності. Це дозволяє своєчасно

Вісник економіки транспорту і промисловості № 60, 2017 
аналізувати зміни в кон'юнктурі ринку та забезпечувати стабільні умови функціонування i розвитку. Для малих підприємств процес бюджетування $\epsilon$ складним та високо затратним, але необхідним залишається здійснення періодичного планування та контролю. На думку авторів, використання елементів бюджетування малого підприємства має стати одним із основних інструментів ведення діяльності цього виду бізнесу. Управління малим підприємством $\epsilon$ досить специфічним, тому i бюджетне управління малим бізнесом має відрізнятися від бюджетування великого та середнього бізнесу. Подальше дослідження має дати відповідь на питання можливості використання бюджетування на малих підприємствах.

Аналіз останніх досліджень i публікацій. Доцільність використання бюджетування на підприємствах підтверджується думкою багатьох вітчизняних учених. Так, О. С. Федорченко зазначає, що система бюджетування підприємства як інструмент внутрішньогосподарського фінансового планування та контролю, суттєво підвищує ефективність управління фінансами підприємства, попереджаючи про нераціональне використання фінансових ресурсів як на стадії планування, так і на стадії контролю за їх використанням [4]. Пропозиція ведення ефективного обліку через створення центрів відповідальності як важлива умова ефективного управління підприємством розглянута у роботі Р. I Жовновача [5]. Зміну принципів управління через високу ентропію зовнішнього середовища розглядає i К. М. Чумак. У зазначеній роботі пропонується розроблення системи бюджетів на підприємстві, що дасть змогу врахувати всі елементи прогнозів, сконцентрувавши їх в бюджеті про доходи та витрати [6]. Недостатньо дослідженим, на думку авторів, залишається відсутність в системі бюджетування показників, орієнтованих на вирішення переважно короткострокових завдань, а також вирішення вузького завдання, що не дозволяє використовувати потенціал бюджетування для малих підприємств.

\section{Метою} дослідження обгрунтування доцільності використання бюджетування реклами малими підприємствами як необхідної умови забезпечення їх конкурентоспроможності.

Виклад основного матеріалу дослідження. Управління малими підприємствами на даний час вимагає від керівників пошуку нових нецінових методів забезпечення конкурентоспроможності. Таким, широко використовуваним методом $\epsilon$ реклама. Запас фінансової міцності малих підприємств не дозволяє використовувати найсучасніші технології просування своєї продукції та послуг, що зменшує їх стійкість перед великими підприємствами, але рекламна стратегія може стати успішною за умови використання керівниками методів планування та контролю. Одним 3 таких методів $\epsilon$ бюджетування реклами. Але, як зазначено у роботі Ліонеля А. Мітчелла: «Методи складання рекламних бюджетів на практиці є більш складними, ніж описані в теорії, але їх використання значно зменшує розрив між малими підприємствами, орієнтованими на маркетинг, і успішними компаніями» [7]. Авторами пропонується виявити місця, що викликають складність та небажання керівників малих підприємств використовувати бюджетування. Для цього, по-перше, пропонуються порівняльні характеристики використання бюджетування реклами підприємствами великого та малого бізнесу зведені авторами до табл. 1. 
Таблиия 1

Характеристики використання бюджетного рекламування підприємств великого та малого бізнесу [Авторська розробка за джерелами [4,5,6]]

\begin{tabular}{|c|c|}
\hline $\begin{array}{c}\text { Характеристики використання } \\
\text { бюджетування реклами підприємств } \\
\text { малого бізнесу } \\
\end{array}$ & $\begin{array}{c}\text { беклами підприємств великого та середнього } \\
\text { бізнес }\end{array}$ \\
\hline $\begin{array}{lcr}\text { бюджетування } & \text { реклами } & \text { означає } \\
\text { створення } & \text { ефективного } & \text { управління } \\
\text { частиною } & \text { фінансових } & \text { ресурсів, } \\
\text { оптимізація витрат і прибутку } & \\
\end{array}$ & $\begin{array}{l}\text { бюджетування реклами означає частину } \\
\text { системи бюджетування, управлінського } \\
\text { обліку, оптимізація витрат і прибутку [4] }\end{array}$ \\
\hline 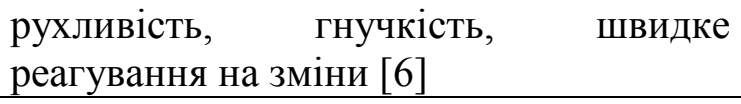 & $\begin{array}{l}\text { рухливість, гнучкість, швидке реагування на } \\
\text { зміни [6] }\end{array}$ \\
\hline $\begin{array}{l}\text { для бюджетування реклами на } \\
\text { підприємстві } \\
\text { використовуватися цільові показники } \\
\text { підприємства, так і прогнозні цифри, } \\
\text { які приймаються на підставі статистики } \\
\text { та рішення керівника. Бюджетування } \\
\text { реклами на підприємстві може } \\
\text { виконуватися за методами: фінансовий, } \\
\text { залишковий. }\end{array}$ & $\begin{array}{l}\text { бюджетування реклами на підприємстві } \\
\text { може виконуватися за методами: фінансовий, } \\
\text { залишковий, розрахунок бюджету у } \\
\text { відсотках від очікуваних річних обсягів } \\
\text { продажу, або валового прибутку, метод на } \\
\text { основі рентабельності витрат та маркетингові } \\
\text { методи. Можуть використовуватись зовнішні } \\
\text { цільові показники компанї, прогнозні цифри, } \\
\text { які розраховуються на підставі статистики, } \\
\text { зібраної безпосередньо в системі [5] }\end{array}$ \\
\hline $\begin{array}{l}\text { iзнесу у } \\
\text { у } \\
\text { дійснення } \\
\text { особиста } \\
\text { ість }\end{array}$ & $\begin{array}{l}\text { головна роль у складанні належить } \\
\text { фінансовому менеджменту, можлива участь } \\
\text { власника бізнесу у в внутрішньо- } \\
\text { підприємницькому бюджетуванні реклами } \\
\text { для більшого контролю [4] }\end{array}$ \\
\hline $\begin{array}{l}\text { бюджетування реклами вимірюється } \\
\text { періодами в залежності від сезонності; } \\
\text { терміни: на період від трьох місяців до } \\
\text { року - довгостроковий, один місяць - } \\
\text { поточний, оперативний }\end{array}$ & 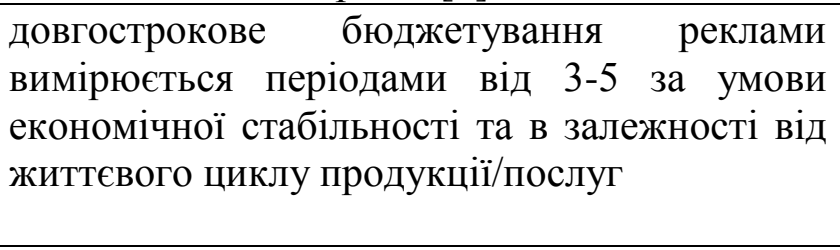 \\
\hline 4] & $\begin{array}{l}\text { ий доступ до фінансових та грошових } \\
\text { в }\end{array}$ \\
\hline $\begin{array}{l}\text { перевантаження головного керівника, } \\
\text { ризик прийняття невірного рішення. } \\
\text { Прийняття рішення здійснюється } \\
\text { «зверху-вниз». Неможливість найняти } \\
\text { висококваліфіковані кадри, можлива } \\
\text { відсутність професійних знань. }\end{array}$ & $\begin{array}{l}\text { процес децентралізований [5], потребує } \\
\text { висококваліфікованих кадрів, програмного } \\
\text { забезпечення. Прийняття } \\
\text { здійснюється «зверху вниз», «знизу-вверх», } \\
\text { «комбіноване». Потребує побудови досить } \\
\text { складної системи } \\
\text { бюджетів, розподілу функцій і повновожажень }\end{array}$ \\
\hline
\end{tabular}

Зазвичай обсяг рекламного бюджету на малих підприємствах визначається керівником виходячи 3 суми коштів, які залишились після покриття інших потреб, або фіксована сума в залежності від доходу фірми, а також можливий варіант встановлення суми бюджету у порівнянні 3 витратами конкурента на рекламну діяльність. Використання бюджетування рекламної діяльності примушує визначитись не тільки з витратами, але 3 плануванням строків рекламування, видів

Вісник економіки транспорту і промисловості № 60, 2017 
реклами, що буде використовуватись та забезпечує зворотній зв'язок зі споживачем.

По-друге, необхідно конкретизувати підприємств

використовувати

бюджетування з метою визначення шляхів їх мінімізації (рис.1). причини небажання керівників малих

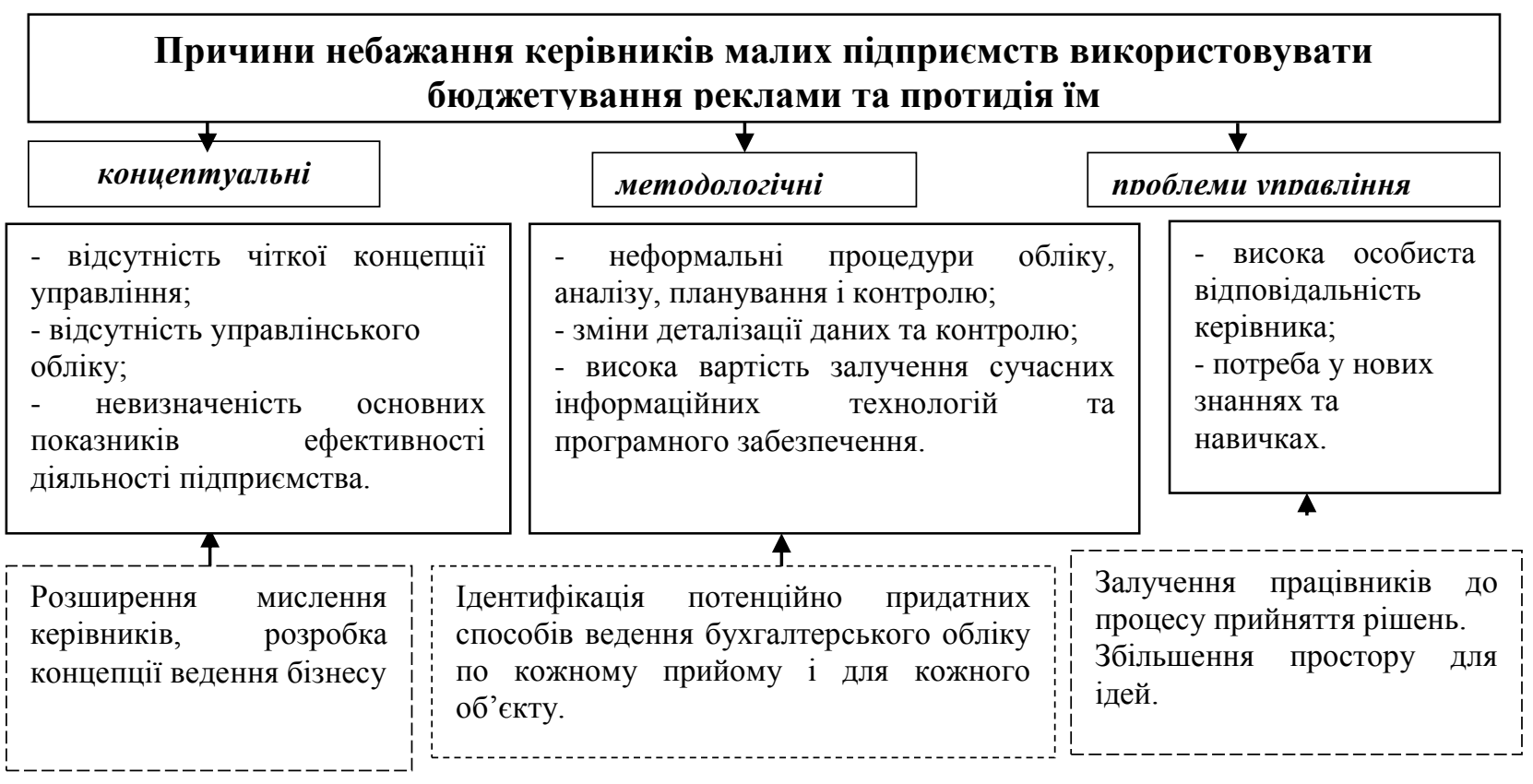

Рис. 1. Причини, які викликають небажання керівників малих підприємств використовувати бюджетування реклами [Авторська розробка за джерелом 4, 5]

Установлено, що головною перешкодою до використання бюджетного планування реклами на малих підприємствах $\epsilon$ небажання самих керівників, або нерозуміння отримання переваг від їх застосування, а також думка про їх надзвичайну складність. Тому управлінцям потрібно надати чіткий, простий та зрозумілий інструмент до використання. Так пропонується до розгляду метод розрахунку виду бюджетування реклами «Виходячи 3 цілей і завдань», який $є$ не складним і вимагає від учасників ринку формувати свої бюджети реклами на основі вироблення конкретних цілей, завдань, які планується вирішити, та оцінки витрат на реалізацію встановлених завдань. Сума усіх витрат i дасть орієнтовну цифру бюджетних асигнувань на рекламу. Послідовність використання методу вказана на рис.2.

Преваги запропонованого методу полягають у тому, що він $є$ простим, вимагає від керівництва чіткого викладу своїх уявлень про взаємозв'язок між сумою витрат, рівень рекламних контактів, інтенсивність, регулярного контролю за збутом, аналіз асортименту продукції. Ефективність використання підприємством бюджетування реклами пропонується підтвердити показниками рентабельності продажів (ROS) та рентабельності продукції (ROP), які контролюють ефективність реалізації продукції. Приклад розрахунку показників у табл. 2. 
Алгоритм виконання бюджетування на рекламу методом «Виходячи 3 цілей і завдань»

Крок 1. Вироблення конкретних цілей рекламного заходу

Інформаційні цілі Збутові цілі

\begin{tabular}{|c|c|}
\hline $\begin{array}{l}\text { Крок 2. Визначення завдань, що треба } \\
\text { буде розв'язати для досягнення цілей }\end{array}$ & $\begin{array}{l}\text { Прийняття рішення по зверненню, прийняття } \\
\text { рішення про засоби поширення інформації }\end{array}$ \\
\hline
\end{tabular}

\begin{tabular}{|c|c|l}
\hline $\begin{array}{c}\text { Крок 3. Оцінка витрат } \\
\text { на вирішення цих } \\
\text { задач }\end{array} \longleftrightarrow \begin{array}{l}\text { Розрахунок витрат на розробку та виготовлення рекламного } \\
\text { повідомлення (реалізація концепції); визначення витрат на } \\
\text { розміщення реклами (реалізація медіа стратегії). }\end{array}$ \\
\hline
\end{tabular}

Крок 4. Оцінка рекламного заходу Перевірка збуту, перевірка інформованості

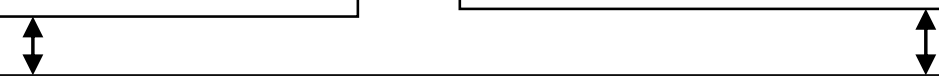

Недоліки. Недостатньо чітко встановлюється взаємозв'язок між кінцевим завданням і обсягами майбутніх і безпосередніх продажів Необхідно постійно співвідносити витрати на майбутні заходи, величина яких визначається на початок рекламного заходу із прибутком, від продажів, що очікуються наприкінці періоду рекламного періоду.

Рис. 2. Алгоритм визначення бюджетування за методом «Виходячи з иүілей $i$ завдань» $[8,9]$

Таблиия 2

Аналіз результатів застосування бюджетування реклами на малому підприємстві

\begin{tabular}{|c|c|c|c|c|c|c|}
\hline Показники & №3/ח & Од. виміру & $2013 p$. & $2014 \mathrm{p}$. & $2015 p$ & $2016 p$. \\
\hline $\begin{array}{l}\text { Чистий прибуток } \\
\text { (Net Profit) }\end{array}$ & 1 & $\begin{array}{l}\text { тис. грн. } \\
\text { (рядок } 220 \text { форми } \\
\text { 2) }\end{array}$ & 152,371 & 179,8357 & 188,355 & 231,751 \\
\hline $\begin{array}{l}\text { Чистий дохід від } \\
\text { реалізації } \\
\text { (Revenue) }\end{array}$ & 2 & $\begin{array}{ll}\text { тис. грн. } & \\
\text { (рядок } & 035 \\
\text { форми2) } & \\
\end{array}$ & 3359,62 & 3210,38 & 3239,70 & 5448,47 \\
\hline $\begin{array}{l}\text { Собівартість } \\
\text { (Cost price) }\end{array}$ & 3 & тис. грн. & 71,2 & 84,82 & 105,50 & 107,791 \\
\hline $\begin{array}{l}\text { Рентабельність } \\
\text { продажів (ROS) }\end{array}$ & 4 & стр.1/стр.2*100\% & 16,51 & 17,9 & 17,2 & 23,51 \\
\hline $\begin{array}{l}\text { Рентабельність } \\
\text { продукції (ROP) }\end{array}$ & 5 & стр.1/стр.3*100\% & 2,14 & 2,12 & 2,1 & 2,15 \\
\hline
\end{tabular}

Таким чином, упровадження бюджетування реклами на досліджуваному підприємстві дало позитивну динаміку ROS, ROP. Як наслідок використання бюджетування реклами, керівник провів аналіз асортименту і ввів деякі зміни, тобто була проведена ідентифікація потенційно придатних способів ведення бухгалтерського обліку, по кожному прийому і для кожного об'єкту, та розробка концепції ведення бізнесу. Керуючись показниками, рекомендованими для економічного обгрунтування, слід пам'ятати, що вони також оцінюють частку собівартості продукції у доході, зміну структури асортименту, зміну відпускних цін та не враховують управлінський характер, інфляцію, зміну попиту. За 
думкою авторів, використання бюджетування реклами на підприємствах малого бізнесу сприяє активізації функції планування та контролю, а отже допомагає керівнику своєчасно реагувати на зміни, що відбуваються у середовищі існування підприємства, тобто змінює управлінську поведінку.

Висновок. Упровадження та застосування бюджетування реклами на малих підприємствах повинне стати важливим інструментом у сукупності заходів формування конкурентних переваг. Планування та контроль реклами підвищує якість управління, дає можливість оптимально використовувати перспективи, що відкриваються в зовнішньому середовищі, забезпечує ефективне використання внутрішніх ресурсів. Недоліком цього методу $є$ залежність прийняття рішення від однієї людини головного керівника, що підвищує ризик неадекватного вибору виду реклами чи іiі інтенсивності, помилки у сегментації ринку або у виборі методу просування тощо. Зменшення таких ризиків 3 метою підвищення ефективності реклами для підприємців малого бізнесу $є$ темою подальшого дослідження.

\section{ПЕРЕЛІК ВИКОРИСТАНИХ ДЖЕРЕЛ}

1. 50 Reasons Why Some Businesses Fail While Others Succeed [Електронний ресурс] // Режим доступу : https://www.successharbor.com/why-somebusinesses-fail-while-others-succeed02132015/ - Загол. з екрану

2. Економічна

статистика.

Економічна діяльність. Промисловість [Електронний ресурс]: офіційні дані Державної служби статистики України. Режим доступу: http://www.ukrstat.gov.ua/

3. Дикань О. В. Розвиток малого бізнесу в Україні: проблеми та шляхи забезпечення [Електронний ресурс] / О. В. Дикань // Вісник економіки транспорту і промисловості. - 2017. - № 57, - 58 с. - Режим доступу до журн. : http://btie.kart.edu.ua/article/view/101559

4. Федорченко О. С. Удосконалення системи бюджетування на підприємстві [Електронний ресурс] / О. С. Федорченко // Економіка та держава. - 2015. - Вип. №11, - 37 с. - Режим доступу до журн.: http://www.economy.in.ua /pdf/11_2015/11.pdf

5. Жовновач Р. I. Постановка системи бюджетування на підприємстві [Електронний ресурс] / Р. І. Жовновач // Наук.-дослідн. фінанс. інститут Мін. фін. України, КНТУ. - 2006. - 333 с. - Режим доступу:

http://dspace.kntu.kr.ua/jspui/bitstream/12345 6789/2416/1/12.pdf

6.Чумак К. М. Система бюджетів як елемент фінансового управління підприємством / К. М. Чумак // Економічні науки.- 2011. -Вип. 2, Т. 2. - 83 с.;

7. Ліонель А. М. Исследование методов составления рекламных бюджетов: практика и литература / А. М. Ліонель // Европейский журнал маркетинга. - 1993. - Vol. 27 Issue: 5. pp.5-21 - Режим доступу: https://doi.org/10.1108/03090569310039697

8. Діброва Т. Г. Процедура планування бюджету рекламної кампанії: комбінований підхід [Електронний ресурс] / Т. Г. Діброва // Економічний вісник Національного технічного університету України "Київський політехнічний інститут". - 2014. - Вип. № 11. - 349 с. Режим доступу: http://nbuv.gov.ua/ UJRN/evntukpi_2014_11_56

9. Андрєєва Т. С. Оцінка стратегічного потенціалу підприємства в контексті впливу факторів зовнішнього середовища / Е. Є. Андрєєва, О. О. Гетьман // Вісник економіки транспорту i промисловості. - 2017. - № 59 - С. 91-101. - Режим доступу до журн. : http://btie.kart.edu.ua/article/view/101559 